\title{
The Nata de Coco Quality Analysis for Making Fiber-Rich Instant Drink Powder
}

\section{Analisis Kualitas Nata de Coco untuk Pembuatan Serbuk Minuman Instan Kaya Serat}

\author{
Natalia Peni ${ }^{a, 1, *}$, Melania Priska ${ }^{b, 2}$ \\ ${ }^{\text {a }}$ Program Studi Pendidikan Matematika, Universitas Flores, Jl. Sam Ratulangi No. XX, Kel. Paupire, Ende -Flores -NTT, Indonesia \\ ${ }^{\mathrm{b}}$ Program Studi Pendidikan Biologi, Universitas Flores, Jl. Sam Ratulangi No. XX, Kel. Paupire, Ende -Flores -NTT, Indonesia \\ ${ }^{1}$ nataliapeni27@gmail.com *; ${ }^{2}$ pika87cutes@gmail.com \\ * corresponding author
}

\section{ARTICLE INFO}

Article history

Received March 30, 2021

Revised June 30, 2021

Accepted October 04, 2021

\section{Keywords}

Fiber

Instan Drink Powder

Nata de Coco

\section{ABSTRACT}

One of the potentials of coconut water that is widely developed in Indonesia is nata de coco. Nata de coco is the result of fermentation of coconut water which is added by Acetobacter xylum. The research aim was to determine the quality of nata de coco as the basic material for making instant drink powder (IDP) which consists of natural flavors of orange, mango, and soursop. The step of the research was making a starter, making nata de coco, making IDP, and testing the quality of IDP (water content, specific gravity, taste, water solubility, and fiber). Data were analyzed using Tukey's significant difference test with a significance of $0.05 \%$. The results showed that the water content of the IDP three flavors was less than 3\%. Mango specific gratify is also higher but the orange flavor is the one of taste that people really like. The level of solubility in water shows that soursop is higher solubility. The fiber content of IDP orange is higher than mango and soursop. Therefore, nata de coco can be used as a raw material for made IDP.

This is an open access article under the CC-BY-SA license.

\section{Pendahuluan}

Nata merupakan salah satu produk olahan makanan dari kumpulan sel bakteri yang memiliki tekstur kenyal, putih menyerupai gel dan terapung pada permukaan cairan. Produk olahan nata dapat dipakai sebagai makanan pengisi es krim, pencampur buah dalam sirup, dan yoghurt. Produk ini menjadi primadona masyarakat khususnya di daerah perkotaan [1].

Nata berasal dari berbagai macam bahan antara lain air kelapa, sari nanas, sari kedelai, dan bahan lain yang mengandung selulosa. Nata de coco adalah produk olahan hasil fermentasi air kelapa oleh bakteri acetobacter xylinium [2]. Pertumbuhan bakteri acetobacter xylinum terjadi pada media yang mengandung gula sehingga terbentuk suatu lapisan kenyal dan sebagian gula disintesis menjadi selulosa atau nata [3]. Nata de coco berfungsi sebagai serat yang dapat memperlancar metabolisme dalam tubuh manusia dan berpotensi sebagai bahan dasar pembuatan serbuk minuman instan [4].

Kandungan serat dan komposisi kimia yang terdapat dalam nata de coco dipengaruhi oleh varietas kelapa dan lama penyimpanan air kelapa. Hal ini didukung oleh penelitian terdahulu yang telah dilakukan oleh [5], mengenai uji kualitas nata de coco dari varietas kelapa sawarna dan mapanget yang dipengaruhi oleh lama waktu penyimpanan air kelapa. Dari penelitian tersebut, diperoleh bahwa kualitas nata de coco yang dihasilkan dari air kelapa varietas sawarna dengan lama penyimpanan selama 6 jam lebih baik daripada kualitas nata de coco yang dihasilkan dari varietas 
mapanget segar (penyimpanan 0 jam), yang digunakan sebagai kontrol. Selain itu, media tumbuh juga mempengaruhi komposisi nata de coco. Pernyataan ini dibuktikan oleh penelitian yang sebelumnya yang menyatakan bahwa media tumbuh nata de coco pada air kelapa matang memiliki komposisi kimia lebih tinggi dari media Hestrin Schramn (HS), yakni berat basah selulosa sebesar $250 \mathrm{~g} / \mathrm{L}$, kelembaban 92,9\%, pH 4,5, ketebalan $15 \mathrm{~mm}$, kekerasan $41 \mathrm{~N}$, daya ikat air 87,14\%, serat kasar 11,25 g, natrium $41 \mathrm{mg}$, kalium 241,5 mg, dan besi 0,07 mg [6].

Dari komposisi kimia tersebut, nata de coco dapat dijadikan sebagai bahan dasar pembuatan serbuk minuman instan (SMI). SMI merupakan produk olahan bahan pangan berupa bubuk dengan karateristik, yakni memiliki luas permukaan yang besar sehingga mudah larut dalam air dan praktis disajikan [7]. SMI mengandung bahan pemanis, perasa, pewarna, dan bahan tambahan makanan lainnya, yang bermanfaat bagi kesehatan untuk memperlancar pencernaan karena mengandung serat alami plantago ovata dan inulin chicory [8]. Serat plantago ovata dan inulin chicory juga terdapat pada nata de coco. Kedua serat ini selain bermanfaat membantu memperlancar buang air besar, juga menurunkan kadar kolestrol dalam darah, dan berperan dalam diet rendah lemak [9-11]. Berdasarkan kandungan dan manfaat serat yang dimiliki oleh nata de coco, maka diperlukan analisis kualitas nata de coco sebagai bahan dasar dalam pembuatan serbuk minuman instan.

Dari masalah tersebut, maka tujuan penelitian ini adalah mengetahui kualitas nata de coco sebagai bahan dasar pembuatan serbuk minuman instan kaya serat plantago ovata dan inulin chicory yang terdiri dari cita rasa alami ekstrak buah jeruk, mangga, dan sirsak. Penelitian ini diharapkan dapat menjadi sumber informasi bagi masyarakat untuk memanfaatkan air kelapa sebagai bahan dasar pembuatan nata de coco. Dari nata de coco yang dihasilkan dapat dijadikan sebagai bahan dasar pembuatan serbuk minuman instan, sehingga dapat meningkatkan perekonomian masyarakat.

\section{Metodologi Penelitian}

Penelitian ini dilaksanakan dari bulan Agustus - November 2020 di Balai Pengawas Obat dan Makanan (BPOM) di Kupang. Pengujian analisis kualitas nata de coco untuk pembuatan minuman serbuk instan meliputi beberapa tahapan, yakni pembuatan starter, pembuatan nata de coco, pembuatan serbuk minuman instan, dan uji kualitas serbuk minuman instan (kadar air, rasa, kelarutan dalam air, dan kadar serat). Hasil data yang diuji selain uji rasa kemudian dianalisis secara statistik menggunakan One Way dan Two Way Anova untuk melihat korelasi antara parameter uji kualitas serbuk minuman instan (SMI) dengan rasa sari buah (jeruk, sirsak, dan mangga) yang ditambahkan, sedangkan untuk hasil uji rasa dianalisis menggunakan One Way Anova untuk melihat pengaruh penambahan sari buah memberikan hasil yang berbeda nyata terhadap tingkat penilaian panelis dalam menilai rasa SMI.

Alat yang digunakan dalam penelitian ini terdiri dari panci stainless, neraca, talenan, gunting, kompor, rak fermentasi, botol, jerigen, gelas ukur, termometer, ayakan 60 mesh, blender, desikator, oven, inkubator. Bahan yang digunakan dalam penelitian ini terdiri dari air kelapa, bakteri acetobacter xylinum, asam cuka, pupuk urea, gula pasir, sari jeruk, sari sirsak, sari manga, air, kertas saring, kertas $\mathrm{pH}$, kertas koran, dan karet elastis.

\subsection{Pembuatan Starter}

Sebanyak satu liter air kelapa yang telah disaring dipanaskan sampai mendidih, setelah itu dimasukan 5 gram pupuk urea, 5 gram gula pasir, $5 \mathrm{ml}$ asam cuka, sambil diaduk hingga larut, dan pH mencapai 3,2. Larutan tersebut kemudian dimasukan dalam keadaan panas ke dalam botol dan dilakukan pendinginan selama 5-7 jam pada suhu $32{ }^{\circ} \mathrm{C}$. Setelah itu diinokulasikan dengan menggunakan bakteri acetobacter xylinum ke dalam botol dan difermentasikan \pm 7 hari [12].

\subsection{Pembuatan Nata de Coco}

Sebanyak 5 liter air kelapa yang telah disaring dipanaskan sampai mendidih, setelah itu dimasukan 15 gram pupuk urea, 15 gram gula pasir, dan $15 \mathrm{ml}$ asam cuka sambil diaduk hingga $\mathrm{pH}$ mencapai 3,2. Larutan tersebut kemudian dimasukan dalam keadaan panas dalam wadah fermentasi dan dilakukan pendinginan selama 5-7 jam pada suhu $32{ }^{\circ} \mathrm{C}$. Setelah larutan dingin, bibit atau starter dimasukan ke dalam wadah fermentasi lainnya sebanyak $6 \mathrm{ml}$ dan dilakukan fermentasi selama 6-7 hari. Untuk menghilangkan rasa asam, nata de coco direndam selama 3 hari dengan menggantikan air perendamannya setiap hari. Nata de coco yang terbentuk kemudian dipotong menjadi kubus- 
kubus kecil dan dimasak hingga mendidih dan dicuci sebanyak tiga kali, sampai rasa asam dari nata de coco hilang [13].

\subsection{Pembuatan Serbuk Sari Buah (Jeruk, Mangga, dan Sirsak)}

Dari ketiga jenis buah, masing-masing diambil sebanyak $1 \mathrm{~kg}$ lalu dicuci bersih dan dikeringkan dengan cara diangin-anginkan. Setelah kering, masing-masing buah dikupas, lalu dipotong dadu tipis. Buah yang sudah dipotong, dimasukan ke dalam oven dan dikeringkan pada suhu $70{ }^{\circ} \mathrm{C}$ selama 8 jam. Sampel buah yang telah kering kemudian diambil, diblender hingga halus, dan diayak menggunakan ayakan 60 mesh [14].

\subsection{Pembuatan Serbuk Minuman Instan}

Nata de coco dikeringkan dalam oven selama 3-5 jam pada suhu $100-105^{\circ} \mathrm{C}$, selanjutnya diblender hingga menjadi serbuk halus, dan diayak dengan ayakan 60 mesh. Selanjutnya serbuk nata de coco diambil sebanyak 5 gram dan dicampur dengan masing-masing serbuk sari buah sebanyak 5 $\mathrm{g}$ (jeruk, mangga, dan sirsak), serta gula pasir yang telah dihaluskan 5 gram dengan perbandingan $1: 1: 1[15]$.

\subsection{Uji Kualitas Minuman Serbuk Instan}

\section{1) Penentuan Kadar Air}

Sebanyak 5 gram sampel ditimbang dalam cawan yang kemudian dikeringkan dalam oven dengan suhu $105^{\circ} \mathrm{C}$ selama 8 jam hingga berat konstan. Dinginkan sampel tadi di dalam desikator dan selanjutnya ditimbang. Kadar air dihitung dengan rumus berikut [16]:

$$
\text { Kadar air }=\frac{\text { Bobot Sampel (Segar }- \text { Kering) }}{\text { Bobot Sampel Segar }} \times 100 \%
$$

2) Uji Rasa

Pengujian rasa menggunakan skala Hedonik diujikan pada 10 orang panelis dengan skala pengujian sebagai berikut:

Tabel 1. Uji Rasa [17]

\begin{tabular}{cc}
\hline Skala Mutu Hedonik & Skala Numerik \\
\hline Sangat Suka & 3 \\
Suka & 2 \\
Tidak suka & 1 \\
\hline
\end{tabular}

3) Uji Kelarutan dalam Air

Sebanyak 1 gram sampel dididihkan dalam $100 \mathrm{ml}$ air selama 30 menit sambil diaduk dan ditambah air yang hilang akibat penguapan. Setelah dididihkan, sampel diendapkan dan dituangkan ke dalam gelas piala, tekan hati-hati sisa air yang tertinggal pada bahan dengan batang pengaduk. Larutan tersebut dicampur dan ekstraknya disaring selagi masih panas, setelah itu diuapkan pada $400 \mathrm{ml}$ air dan keringkan residu sampai bobot tetap pada suhu $100-105^{\circ} \mathrm{C}$ [16].

\section{4) Uji Kadar Serat}

Ditimbang 1 gram sampel, masukkan dalam labu erlemeyer yang berukuran $250 \mathrm{ml}$. Sampel kemudian dilarutkan dengan $100 \mathrm{~mL} \mathrm{H}_{2} \mathrm{SO}_{4} 1,25 \%$ dan dididihkan. Selanjutnya didestruksi selama 30 menit lalu disaring menggunakan corong Buchner. Endapan dibilas dengan 20-30 mL air mendidih dan dengan $25 \mathrm{~mL}$ air sebanyak 3 kali. Residu didestruksi kembali dengan $\mathrm{NaOH}$ 1,25\% selama 30 menit. Setelah itu dilakukan penyaringan dan disemprot berturut-turut dengan $25 \mathrm{~mL}$ $\mathrm{H}_{2} \mathrm{SO}_{4} 1,25 \%$ mendidih, $25 \mathrm{~mL}$ air sebanyak 3 kali dan $25 \mathrm{~mL}$ alkohol. Residu ditimbang dan dimasukkan dalam tanur $600{ }^{\circ} \mathrm{C}$ selama 30 menit. Setelah itu didinginkan dan ditimbang kembali. Analisis serat kasar dapat dihitung dengan rumus berikut [16]:

$$
\text { Kadar serat kasar }=\frac{\text { Bobot Serat Kasar }}{\text { Bobot Sampel }} \times 100 \%
$$

\subsection{Analisis Data}

Data yang diperoleh kemudian dianalisis secara statistik menggunakan metode One Way Analysis of Variant (Anova) pada perangkat lunak SPSS Versi 20. Tujuannya untuk mengetahui pengaruh penambahan sari buah dalam SMI terhadap tingkat penilaian panelis dalam menilai rasa serbuk minuman instan. Korelasi antara parameter uji kualitas SMI dengan varian rasa buah yang 
ditambahkan dianalisis menggunakan Two Way Anova. Hasil uji korelasi dianalisis lanjut dengan One Way Anova. Apabila terdapat perbedaan yang signifikan antara berbagai uji kualitas SMI, maka dilakukan uji beda nyata Tukey pada taraf signifikan $0,05 \%[18,19]$.

\section{Hasil dan Pembahasan}

\subsection{Kadar Air}

Dari hasil penelitian diperoleh kadar air seperti pada Tabel 2.

Tabel 2. Kadar Air Serbuk Minuman Instan (SMI) Varian Rasa

\begin{tabular}{ccc}
\hline Nama sampel & Kadar air (\%) & Standar (SNI, 1995) \\
\hline SMI Rasa Jeruk & 0,9897 & $3 \%$ \\
SMI Rasa Mangga & 0,4224 & \\
SMI Rasa Sirsak & 0,5024 & \\
\hline
\end{tabular}

Data dari Tabe1 2. menunjukkan bahwa kadar air serbuk minuman instan (SMI) dari 3 (tiga) varian rasa memenuhi standar karena hasil yang diperoleh masih dibawah ambang batas standar yang ditetapkan oleh Balai Pengawas Obat dan Makanan (BPOM) yaitu tidak lebih dari 3\% berdasarkan SNI 01-3722-1995 [20]. Adanya kadar air yang rendah tersebut menyebabkan SMI mudah larut dalam air, karena ikatan antar partikel dalam SMI mudah putus [21].

Dalam serbuk minuman semakin kecil kadar air, serbuk minuman tersebut akan semakin tahan lama dan awet [22]. Tabel 2. juga memperlihatkan bahwa perbedaan penguat rasa berefek juga pada perbedaan kadar air dari setiap SMI yang dihasilkan. Kadar air merupakan komponen penting dalam bahan makanan karena pengaruh penampakan tekstur serta cita rasa makanan tersebut [23]. Tingginya kadar air pada SMI rasa jeruk saat diekstraksi karena terjadi polimerisasi antara glukosa (setiap 2 monosakrida) selalu dihasilkan oleh molekul air dalam keadaan bebas [24].

Molekul air dalam keadaan bebas berikatan secara fisik oleh molekul dan mengisi jaringan makromolekul polimer yang terdapat pada nata de coco. Oleh karena itu pada proses polimerisasi berlangsung, SMI rasa jeruk membutuhkan polimerisasi yang panjang. Rendahnya kadar air pada SMI rasa mangga dan sirsak disebabkan karena rantai polimer yang terbentuk pada proses polimerisasi diperkirakan tidak sepanjang SMI rasa jeruk, sehingga molekul air yang dihasilkan dalam polimerisasi tersebut berjumlah sedikit, akibatnya SMI rasa manga dan jeruk kadar airnya sedikit [25].

\subsection{Rasa}

Rasa dinilai dari adanya respon panelis terhadap indera pengecap (lidah) [26,27]. Uji skala Hedonik membuktikan bahwa SMI rasa jeruk berbeda dengan SMI rasa mangga dan sirsak. Hasil uji ditampilkan pada Gambar 1.

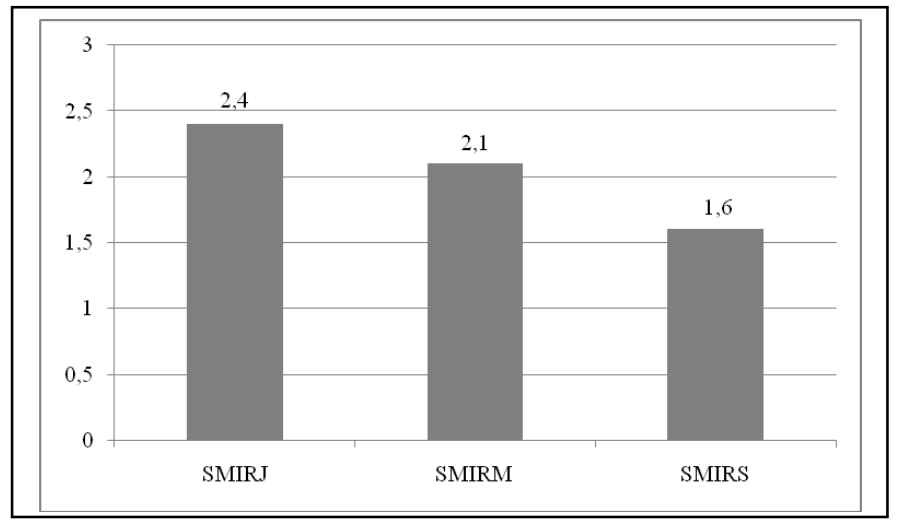

Gambar 1. Perbedaan Rasa Serbuk Minuman Instan Rasa Jeruk (SMIRJ), Serbuk Minuman Instan Rasa Mangga (SMIRM), Serbuk Minuman Instan Rasa Sirsak (SMIRS)

Pada Gambar 1 telihat bahwa kesan rasa sangat suka dengan skor 2,4 terdapat pada SMI rasa jeruk (SMIRJ), sedangkan SMI rasa mangga (SMIRM) dan sirsak (SMIRS) yang memberikan kesan 
antara rasa suka dan tidak suka dengan skor 2,1 dan 1,6. Kesan rasa suka pada SMIRJ dikarenakan adanya rasa asam dan manis pada jeruk, sehingga meningkatkan kesukaan sensori terhadap rasa SMIRJ [28]. Rasa asam pada SMIRJ berasal dari berbagai jenis asam organik, salah satunya adalah asam sitrat. Asam sitrat mudah larut dalam air, dan terurai menjadi karbon dioksida dan air jika dipanaskan di atas suhu $175{ }^{\circ} \mathrm{C}$. Pada pembuatan sari jeruk, suhu yang digunakan dalam pengeringan buah jeruk adalah $70{ }^{\circ} \mathrm{C}$, sehingga tidak menguraikan asam sitrat dan tidak mengubah rasa SMIRJ [29].

\subsection{Kelarutan dalam Air}

Dari hasil analisis, diperoleh bahwa kelarutan serbuk minuman instan dalam air ditunjukkan pada Tabel 3 .

Tabel 3. Kelarutan Serbuk Minuman Instan (SMI) Varian Rasa dalam Air

\begin{tabular}{cc}
\hline Nama Sampel & Kelarutan dalam Air (\%) \\
\hline SMI Rasa Jeruk & 9,5861 \\
SMI Rasa Mangga & 5,7083 \\
SMI Rasa Sirsak & 23,4871 \\
\hline
\end{tabular}

Untuk mengetahui tingkat kelarutan serbuk minuman instan (SMI) dalam air, maka setiap sampel ditimbang \pm 1 gram sampel dengan menggunakan timbangan merk ADAM tipe/seri pw 254 dan dilarutkan dengan $100 \mathrm{~mL}$ air dalam beaker gelas $250 \mathrm{~mL}$ dan diaduk secara perlahan selama 30 menit dan diuapkan pada hot plate. Hasil kelarutan menunjukkan bahwa SMI yang dihasilkan dari 3 (tiga) rasa semuanya dapat larut dalam air. Kelarutan yang tertinggi adalah SMI rasa sirsak, yakni $23,4817 \%$. Tingginya kelarutan SMI rasa sirsak ini menunjukkan bahwa penambahan sari buahbuahan yang memiliki daya larut yang berbeda-beda sangat berpengaruh terhadap kelarutan SMI tersebut dalam air [30].

\subsection{Kadar Serat}

Hasil analisis menunjukkan bahwa SMI rasa jeruk memiliki kadar serat lebih tinggi dibandingkan SMI rasa mangga dan sirsak. Hasil uji dapat dilihat pada Tabel 4.

Tabel 4. Hasil Analisis Kadar Serat Serbuk Minuman Instan (SMI) Varian Rasa

\begin{tabular}{cc}
\hline Nama Sampel & Kadar Serat (\%) \\
\hline SMI Rasa Jeruk & 3,2571 \\
SMI Rasa Mangga & 2,6566 \\
SMI Rasa Sirsak & 2,3756 \\
\hline
\end{tabular}

Data pada Tabel 4 memperlihatkan tingginya kadar serat dari SMI rasa jeruk tidak hanya karena penguat rasa tetapi juga dari bahan bakunya, yakni nata de coco yang mempunyai kadar serat yang tinggi sebesar 3,38\%, dimana mengandung banyak selulosa ekstraseluler yang terkandung dalam air kelapa [31]. Komponen karbohidrat inilah yang menentukan terbentuknya serat pada SMI, dimana adanya korelasi positif antara ketebalan nata dengan pembentukan serat [32].

Tingginya kadar serat dari SMI rasa jeruk $(3,2571 \%)$ menunjukkan bahwa SMI rasa jeruk lebih bagus untuk dikonsumsi oleh manusia sebagai minuman serbuk yang memiliki nilai gizi tinggi dan dapat menurunkan berat badan, memperlancar pencernaan, menurunkan kolestrol dalam darah, dan berbagai penyakit kronis lainnya [33,34].

\subsection{Korelasi Antara Parameter Kualitas Serbuk Minuman Instan (SMI) Dengan Rasa Sari Buah (Jeruk, Mangga, dan Sirsak) Yang Ditambahkan}

Untuk mengetahui korelasi antara parameter uji kualitas serbuk minuman instan (SMI) dengan rasa yang ditambahkan, data dianalisis dengan menggunakan uji One Way dan Two Way Anova. Hasil korelasi dapat dilihat pada Gambar 2. 


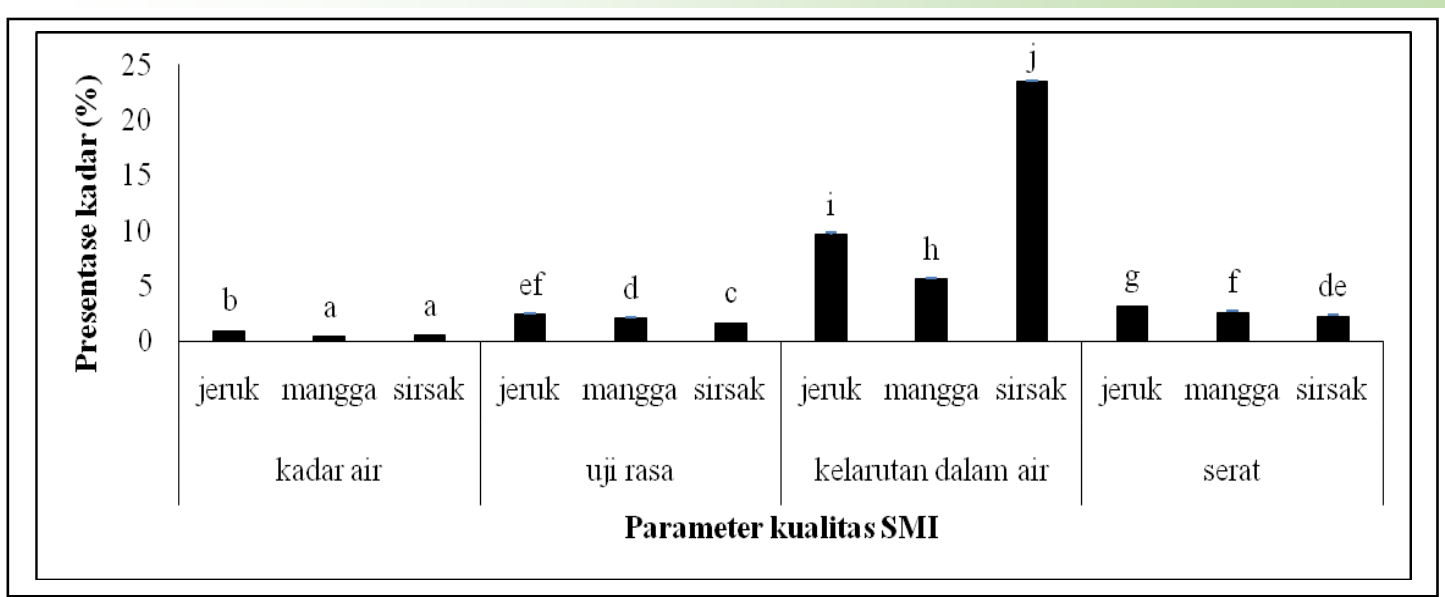

Gambar 2. Korelasi Penambahan Rasa Buah (Jeruk, Sirsak, dan Mangga) terhadap Parameter Kualitas Serbuk Minuman Instan (SMI)

Gambar 2 menunjukkan bahwa terdapat beda nyata antara setiap parameter kualitas SMI dengan sari buah yang ditambahkan. Perbedaan yang sangat signifikan terdapat pada parameter kelarutan dalam air dengan jenis sari buah yang ditambahkan, ditunjukan dengan notasi i, h, dan j. Namun, kadar air, uji rasa, dan serat juga menunjukkan beda nyata antara jenis sari buah yang ditambahkan. Hal tersebut ditunjukkan dengan adanya perbedaan yang signifikan antara kadar air SMI rasa mangga dan sirsak notasi a dengan SMI rasa jeruk notasi b. Hasil uji rasa pada ketiga SMI rasa jeruk, mangga, dan sirsak ditunjukan dengan notasi yang berbeda, yakni ef, d, dan c karena ada perbedaan rasa yang signifikan. Selanjutnya untuk uji kadar serat, juga terdapat perbedaan yang signifikan antara SMI rasa jeruk, mangga, dan sirsak. Hasil ditunjukan dengan notasi g, $\mathrm{f}$, dan de [35].

Penambahan jenis dan komponen nutrisi dalam sari buah sangat berpengaruh terhadap kualitas SMI, dimana terdapat interaksi dan korelasi antara parameter kualitas SMI dengan jenis rasa buah (signifikan <0,05) [36]. Korelasi yang ditunjukkan berdasarkan pearson correlation test terdapat korelasi positif dan negatif. Sari buah yang ditambahkan dalam SMI berkorelasi negatif dengan kadar air, rasa, dan kadar serat, sedangkan kelarutan dalam air berkorelasi positif dengan jenis sari buah yang ditambahkan. Korelasi negatif tersebut menunjukan bahwa semakin banyak jumlah sari buah yang ditambahkan maka semakin tinggi kadar air, rasa, dan serat [37]. Korelasi positif menunjukkan bahwa semakin banyak jenis sari buah yang ditambahkan maka semakin sedikit kadar kelarutan dalam air, dan sebaliknya semakin sedikit sari buah yang ditambahkan semakin banyak kadar kelarutan dalam air [38].

\section{Kesimpulan}

Berdasarkan penelitian yang dilakukan dapat disimpulkan bahwa nata de coco dapat dijadikan sebagai bahan baku pembuatan serbuk minuman instan (SMI) karena hasil yang diperoleh masih memenuhi standar kualitas serbuk minuman instan yang ditetapkan oleh Badan Pemeriksaan Obat dan Makanan (BPOM) berdasarkan SNI 01-3722-1995. Kelebihan dari produk minuman serbuk minuman instan ini adalah tahan lama, pemberi aroma bahan makan, dan pangan fungsional.

\section{Ucapan Terima Kasih}

Ucapan terima kasih peneliti sampaikan kepada Balai Pengawas Obat dan Makanan (BPOM) Kupang dan Lembaga Penelitian dan Pengabdian kepada Masyarakat Universitas Flores yang telah mendukung dan memfasilitasi pelaksanaan penelitian.

\section{Daftar Referensi}

[1] D. Rose, P. Ardiningsih, dan N. Idiawati, "Karakteristik nata de jackfruit (artocarpus heterophyllus) dengan variasi konsentrasi starter acetobacter xylinum," Jurnal Kimia Khatulistiwa, vol. 7(4), hal. 1-7, ISSN: 2303-1077, 2018.

[2] P. Layuk, M. Lintang, dan G. H. Joseph, "Pengaruh waktu fermentasi air kelapa terhadap produksi dan kualitas nata de coco," Buletin Palma, vol. 13(1), hal. 41-45, 2012. 
[3] Y. G. Maloringan dan D. A. Nugroho, "Production of nata de coco using soaked soybean water as the alternative usage of zwavelzuur ammoniak (za). icoa conference proceedingsthe 3rd international conference on agro-industry 2016 "competitive \& sustainable agro-industry: value creation in agribusiness” volume 2017,” KnE Life Sciences, pages 43-50, DOI 10.18502/kls.v4i2.1656. 2018.

[4] C. Anam, M. Z. Zaman, dan U. Khoirunnisa, "Mengungkap senyawa pada nata de coco sebagai pangan fungsional," Jurnal Ilmu Pangan dan Hasil Pertanian, vol. 3(1), hal. 42-53, 2019.

[5] B, Santosa, W. Wignyanto, N. Hidayat, dan S. Sucipto, "The quality of nata de coco from sawarna and mapanget coconut varieties to the time of storing coconut water," Food Research, vol 4(4), hal. 957-963, 2020.

[6] G. Gayathry, "Production of nata de coco - a natural dietary fibre product from mature coconut water using gluconacetobacter xylinum (sju-1)," Intl. J. Food. Ferment. Technol, vol. 5(2), hal. 231-235, 2015.

[7] S. B. Ariska dan D. Utomo, "Kualitas minuman serbuk instan sereh (cymbopogon citratus) dengan metode foam mat drying," Teknologi Pangan: Media Informasi dan Komunikasi Ilmiah Teknologi Pertanian, vol. 11(1), hal. 42-51, 2020.

[8] I. Rasyid, R. Soegih, dan D. S. Harbuwono, "Pengaruh suplementasi serat psyllium husk dan diet rendah kalori seimbang terhadap berat badan, kadar kolestrol high-density lipoprotein, dan trigliserida serum pada obes i,” Jurnal Gizi Klinik Indonesia, vol. 11(4), hal. 1-11, 2014.

[9] A. Herminiati, "Umbi dahlia: potensi, peranan, dan prospek pengembangannya," PANGAN, vol. 21(4), hal. 397-406, 2012.

[10]J. Slavin, "Fiber and prebiotics: mechanisms and health benefits," Nutrients, Vol. 5, hal. 1417- 1435, 2013.

[11]R. N. Yulia, V. Tambunan, dan A. R. Prijanti, "Pengaruh suplementasi serat psyllium husk dan diet rendah kalori seimbang terhadap kadar apo b penyandang obes i," Jurnal Argipa: Arsip Gizi dan Pangan, vol. 1(2), hal. 121-128, 2016.

[12] A. Hamad, N. A. Handayani, dan E. Puspawiningtyas, "Pengaruh umur starter acetobacter xylinum terhadap produksi nata de coco," Techno, vol. 15(1), hal. 37-49, 2014.

[13]F. Nurdyansyah dan D. A. Widyastuti, "Pengolahan limbah air kelapa menjadi nata de coco oleh ibu kelompok tani di kabupaten Kudus,” JKB, vol. 21(11), hal. 22-30, 2017.

[14] Y. I. Susanti dan W. D. R. Putri, "Pembuatan minuman serbuk markisa merah (passiflora edulis f. edulis sims) (kajian konsentrasi tween 80 dan suhu pengeringan)," Jurnal Pangan dan Agroindustri, vol. 2(3), hal. 170-179, 2014.

[15]L. Wibowo dan E. Fitriyani, "Pengolahan rumput laut (eucheuma cottoni) menjadi serbuk minuman instan," Vokasi, vol. 8(2), hal. 101-109, 2012.

[16]AOAC, Official Methods of Analysis, AOAC Publisher, Washington DC, 1995.

[17] I. P. Tarwendah, "Studi komparasi atribut sensoris dan kesadaran merek produk pangan,” Jurnal Pangan dan Agroindustri, vol. 5(2), hal. 66-73, 2017.

[18] Murdinah, "Penggunaan alginat dalam pembuatan serbuk effervescent sari jeruk lemon," JPHPI, vol. 18(2), hal. 177-189, 2015.

[19] M. F. P. Firdaus, S. P. Madyawati, N. S. Widjaja, M. Lamid, K. Rachmawati, dan S. H. Warsito, "Efektivitas penambahan kombinasi tujuh enzim terhadap estimasi pertambahan berat badan sapi potong peranakan sentimental," Agroveteriner, vol. 2(1), hal. 1-7, 2013.

[20]E. Oktaviani, "Penentuan kadar flavonoid dan aktivitas antioksidan formula serbuk minuman instan ekstrak belimbing," Fitofarmaka Jurnal Ilmiah Farmasi, vol. 8(1), hal. 1-12, 2018.

[21]D. A. Permata dan K. Sayuti, "Pembuatan minuman serbuk instan dari berbagai bagian tanaman meniran (phyllanthus niruri)," Jurnal Teknologi Pertanian Andalas, vol. 20(1), hal. 44-49, 2016.

[22]F. Indriaty, dan Y. F. Assah, "Pengaruh penambahan gula dan sari buah terhadap kualitas minuman serbuk daging buah pala,” Jurnal Penelitian Teknologi Industri, vol. 7(1), hal. 49-60, 2015. 
[23]H. D. Hutomo, F. Swastawati, dan L. Rianingsih, "Pengaruh konsentrasi asap cair terhadap kualitas dan kadar kolestrol belut (monopterus albus) asap,” Jurnal Pengolahan dan Bioteknologi Hasil Perikanan, vol. 4(1), hal. 7-14, 2015.

[24]A. U. Mas'ula dan H. T Palupi, "Pengaruh penambahan pectin kulit jeruk dan sukrosa terhadap karakteristik fisikokimia dan organoleptik selai jahe (zingiber officinale)," Jurnal Teknologi Pangan, vol. 9(2), hal. 132-139, 2018.

[25] S. Rahmawati, C. L. Radiman, M. A. Martoprawiro, S. Nuryanti, dan A. Ma'ruf, "Analisis teori fungsional kerapatan struktur membran nata de coco tersulfonasi," Chimica et Natura Acta, vol. 7(2), hal. 87-90, 2019.

[26]R. M. S. Putri dan S. N. Amrizal, "Optimasi formula minuman fungsional serbuk minuman instan dari brunok (acaudina molpadioides) dengan metode pengeringan busa (foam mat drying)," Akuatikisle: Jurnal Akuakultur, pesisir dan Pulau-Pulau Kecil, vol. 4(2), hal. 73-78, 2020.

[27]A. Setiawan dan D. Pujimulyani, "Pengaruh penambahan ekstrak jahe terhadap aktivitas antioksidan dan tingkat kesukaan minuman instan kunir putih (curcuma mangga val.). prosiding seminar nasional “inovasi pangan lokal untuk mendukung ketahanan pangan”," Yogyakarta: Universitas Mercu Buana, ISSN: 2656-6796, 2018.

[28] I. Triastuti, F. Nurainy, O. Nawansih, "Kajian produksi minuman campuran sari wortel dengan berbagai buah,” Jurnal Teknologi Industri dan Hasil Pertanian, vol. 18(2), hal. 101-113, 2013.

[29] L. Cindaramaya dan M. N. Handayani, "Pengaruh penggunaan asam alami terhadap karakteristik sensori dan fisikokimia fruit leather labu kuning," vol. 4(1), hal 41-50, 2019.

[30]B. Haryanto, "Pengaruh penambahan gula terhadap karakteristik bubuk instan daun sirsak (annona muricata 1.) dengan metode kristalisasi," Jurnal Penelitian Pascapanen Pertanian, vol. 14(3), hal. 163170, 2017.

[31]K. Putranto dan A. Taofik, "Penambahan ekstrak toge pada media nata de coco," Jurnal Istek, vol. 10(2), hal. 138-149, 2017.

[32]F. A. Amrullah, Liman, dan Erwanto, "Pengaruh penambahan berbagai jenis sumber karbohidrat pada silase limbah sayuran terhadap kadar lemak kasar, serat kasar, protein kasar dan bahan ekstrak tanpa nitrogen," Jurnal Ilmiah Peternakan Terpadu, vol. 3(4), hal. 221-227, 2015.

[33]A. Santoso, "Serat pangan (dietary fiber) dan manfaatnya bagi kesehatan," Magistra, vol. 23(75), hal. 35-40, 2011.

[34] Ratnaningsih, E. Ginting, M. M. Adie, dan D. Harnowo, "Sifat fisikokimia dan kandungan serat pangan galur-galur harapan kedelai,” Jurnal Penelitian Pascapanen Pertanian, vol. 14(1), hal. 35-45, 2017.

[35]N. Retnaningsih dan A. I. N. Tari, "Analisis minuman secang: tinjauan proporsi putih telur, maltodekstrin, dan kelayakan usahanya,” Agrin, vol. 18(2), hal. 129-147, 2014.

[36] M. A. Hidayat, N. Herawati, dan V. S. Johan, "Penambahan sari jeruk nipis terhadap kaarakteristik sirup labu siam,” JOM FAPERTA UR, vol. 4(2), hal. 1-15, 2017.

[37]E. F. B. Sebayang, R. J. Nainggolan, dan L. M. Lubis, "Pengaruh perbandingan bubur kweni dengan sari jeruk manis dan jumlah gelatin terhadap mutu marshmallow," Jurnal Rekayasa Pangan dan Pertanian, vol. 5(1), hal. 81-88, 2017.

[38]E. Widowati, N. H. R. Parnanto, dan Muthoharoh, "Pengaruh enzim poligalakturonase dan gelatin dalam klarifikasi sari buah naga super merah (hylocereus costaricensis), Jurnal Teknologi Hasil Pertanian, vol. 8(1), hal. 56-69, 2020. 